\title{
Does the Addition of Explicit Clarification of Auditor Independence Statement to the Auditor's Report Matter to Equity Analysts?
}

\author{
Xia Zhang ${ }^{1} \&$ Kwadwo Ofori-Mensah ${ }^{2}$ \\ ${ }^{1}$ College of Business and Public Affairs, Alabama A\&M University, 4900 Meridian St. N., Huntsville, AL, 35811, \\ U.S.A. \\ ${ }^{2}$ Robbins College of Business and Entrepreneurship, Fort Hays State University, 600 Park St, Hays, KS 67601 \\ U.S.A.
}

Correspondence: Xia Zhang, College of Business and Public Affairs, Alabama A\&M University, 4900 Meridian St. N., Huntsville, AL, 35811, U.S.A.

Received: January 31, 2019

Accepted: April 9, 2019

Online Published: April 15, 2019

doi:10.5430/afr.v8n2p156

URL: https://doi.org/10.5430/afr.v8n2p156

\begin{abstract}
The Public Company Accounting Oversight Board (PCAOB) adopted a new auditing standard to enhance the relevance and usefulness of the auditor's report. One of the changes introduced in the new reporting model is the addition of a statement that explicitly clarifies the auditor's independence (AS 3101.09.g). We administer a survey to investigate whether explicitly clarifying the auditor's independence in the auditor's report affects equity analysts' perceptions of auditor independence, perceptions of financial reporting reliability, and their judgment when it comes to making stock recommendations to clients. A total of 123 equity analysts are recruited via Qualtrics for the study. The findings of the survey provide evidence that corroborates the position of the PCAOB that explicit clarification of auditor independence provides relevant information useful to public users such as equity analysts. Our study is the first to evaluate equity analysts' perceptions about auditor independence using the new PCAOB auditor reporting model regarding the explicit clarification of auditor independence in the auditor's report. Our study contributes to research, practice, and policy.
\end{abstract}

Keywords: explicit clarification, auditor independence, stock recommendations

\section{Introduction}

The auditor's report is the primary communication vehicle between auditors and financial statement users, such as investors and lenders, regarding the audit of the financial statements prepared by management (PCAOB 2013). Per Statement of Financial Accounting Concepts, SFAC No. 1, FASB 1978, "financial statements are audited by independent accountants for the purpose of enhancing confidence in their reliability" (FASB 1978). Financial statement users recognize that there is richer information about the firm and about the audit itself than what is provided through the audit report. These recognized differences prompted major financial reporting regulators, like the Auditing Standards Board (AICPA, 2010), and the International Auditing and Assurance Standards Board (IAASB, 2011) to implement changes to the Standard Audit Report. One of the newly adopted changes requires auditors to explicitly clarify in the audit report that "the auditor is a public accounting firm registered with the PCAOB (United States) and is required to be independent with respect to the company in accordance with the U.S. federal securities laws and the applicable rules and regulations of the SEC and the PCAOB (PCAOB, 2017 AS $3101.09 . \mathrm{g}$ ). This new format of the auditor's report is aimed at boosting users' confidence in financial reports and enhancing the relevance and usefulness of the report. On October 23, 2017 the Securities and Exchange Commission (SEC) unanimously approved the new standard, AS 3101, The Auditor's Report on an Audit of Financial Statements When the Auditor Expresses an Unqualified Opinion (SEC 2017).

The main focus of this paper is to investigate whether the inclusion of a clarification statement about auditor independence would provide useful information regarding the auditor's responsibilities to be independent and corroborate the view of the PCAOB. Explicitly clarifying the auditor's independence in the auditor's report is one of the new additions to the standard audit report. Since the inclusion of auditor independence in the report is a new concept, it calls for empirical investigation into the underlying premise of the PCAOB. As of now Ofori-Mensah, Zhang, and Booker (2018) is the only known published paper which deals exclusively with the addition of 
clarification of auditor independence statement and its impact on users' perceptions about auditor independence. The key distinction between the current study and Ofori-Mensah et al. (2018) rests in different research design. The former study uses an experiment, while this study uses a survey of 11 questions in three dimensions to assess respondents' perceptions of auditor independence in the new audit report regarding the addition of the explicit clarification of auditor independence statement. The findings of our survey suggest that the explicit clarification of auditor independence statement enhances users' perceptions of auditor independence and financial reporting reliability, thus confirming the finding of Ofori-Mensah et al. (2018).

Regulators often claim that users' confidence in a company's audited financial statements is one of the key factors that underlie the efficient functioning of the markets for public companies' securities. However, this confidence can only exist if reasonable investors and analysts perceive auditors as independent third-party expert professionals who can be relied on to produce unbiased reports (PCAOB, 2013, 9). It is common knowledge that if auditors fail to detect significant misrepresentations in a company's financial statements, it can lead not only to losses for lenders and investors, but also to an overall decline of trust in capitalist institutions. This thinking underlies the importance users of financial reports attach to auditor independence that ensures objective financial reporting.

Thus, this study investigates the claim by the PCAOB that more disclosure in the standard audit report (to include the clarification statement on auditor independence) means more relevant information made available to users of financial statements. Would the disclosure of auditor independence reduce the alleged information asymmetry that exists between company management and users of financial reports and assure users of the auditor's independence? Research suggests that audits increase the credibility and reliability of management-provided financial information (Church, Jenkins, \& Stanley, 2018). However, will the addition of auditor independence statement reduce questions about the motives of the certifier and create trust between investors and managers, as Davis (2011) suggests?

The results of our study are intended to provide the needed feedback to regulators and users of financial reports including academics and other practitioners. Our study finds that the addition of auditor independence clarification statement increases users' confidence in financial reports, which in turn positively impacts their perceptions of auditor independence, financial reporting reliability, and their judgments when they make investing recommendations. Respondents to our online survey believe that the explicit clarification of independence in the auditor's report serves as a constant reminder to auditors of their obligations to be independent of the company being audited. The perception that the auditor is independent and objective inspires greater confidence in the auditor's opinion, thus increasing the reliability of reported accounting numbers (Ryan, Herz, and Iannaconi, 2001).

The remainder of this paper is organized as follows. We develop our hypotheses in the next section, followed by the research methods, and the results. The last section concludes the paper.

\section{Literature Review and Hypotheses}

\subsection{Background}

Audited financial statements and related disclosures are the major source of information to professional users such as equity analysts who make investment-related decisions. A perception that the auditor's work is more objective and independent inspires greater confidence in the auditor's opinion, which increases the perceived reliability of reported accounting numbers (Elliot and Jacobson, 1998). Research shows that the efficiency of global markets and the well-being of the investing public depend on the quality, reliability, and transparency of the information provided by audited financial statements and the accompanying notes (Tepalagul and Lin, 2015; Barlev, Citron, Haddad, and Rene, 2017). The PCAOB posits that the explicit clarification of auditor independence will add to the attributes listed by these earlier researchers. AS 3101 goes further to assert that the explicit clarification of auditor independence will reduce the level of information asymmetry between company management and analysts which could result in more efficient capital allocation and lower the average cost of capital as suggested by Easley and O'Hara (2004). Thus, the assurance of independence is crucial to all those who rely on audited financial statements for reliable information regarding a firm's financial health, especially investors, lenders, employees and partners (Moore, Tetlock, and Tanlu, 2006).

\subsection{Literature Review}

\subsubsection{Auditor Independence}

James Doty, the former chairman of the PCAOB is on record for saying that "independence is the rock on which the audit profession takes its stand" (Doty 2015). Auditor independence in appearance or auditor independence in fact is considered as the cornerstone of the public accounting practice. Auditor independence rules are set by different government agencies and standard-setting bodies such as the U.S. Securities and Exchange Commission (SEC), the 
PCAOB, the American Institute of Certified Public Accountants (AICPA), U.S. Government Accountability Office (GAO). Auditor independence in fact is associated with the auditor's mindset, referring to a state of mind that is "partly synonymous with honesty, integrity, courage, and character" (Carey 1946, 7). Church and Zhang (2002) argue that independence in fact is necessary to enhance the reliability of financial statements. On the other hand, independence in appearance is necessary to promote public confidence such that users will continue to rely on audited financial statements.

Regulators and oversight bodies such as the SEC and the PCAOB have focused their rulemaking and enforcement activities almost exclusively on independence in appearance (Church et al., 2018). Independence in appearance centers on the nature of the auditor-client relationship, which entails whether others believe that the auditor is impartial and free of conflicts of interest (SEC 2001). The AICPA acknowledges the importance of perceptions of auditor independence when it asserts that "Independent auditors should not only be independent in fact; they should avoid situations that may lead outsiders to doubt their independence." As a result, the code explicitly requires not only actual independence from audit clients, but also encourages the appearance of independence to third parties.

\subsubsection{Source Credibility Theory}

Due to the desire to reduce the uncertainty usually associated with information evaluation, analysts and other users of financial information have been yearning for more disclosures in the financial reporting process. Analysts and other financial statement users see the auditor as a third-party credible source of new and persuasive information besides that produced by management (Brinol and Petty, 2009). Source credibility theory implies that when investors are faced with uncertainties in making investment decisions, they turn to audited reports because they view those reports as coming from trustworthy, expert sources outside the firms. As Holt and DeZoort (2009) point out, trustworthiness and expertise are the yardsticks for measuring information persuasiveness and source credibility. Since the auditor is a third party, independent outsider, there is a perception that the auditor's work is more objective, and this objectivity inspires greater confidence in auditor's opinion, which increases the reliability or quality of reported accounting numbers (Ryan et al., 2001).

Since auditors are independent operatives they are perceived as credible sources who are more likely to prevent or detect material misstatements either due to fraud or errors, and to ensure that financial statements comply with generally accepted accounting principles. Clarification of auditor independence is expected to translate into greater transparency in the financial reporting process, thereby allowing analysts and other decision makers to decrease their cognitive effort and rely on auditors' attribute as credible source during information processing (Holt and DeZoort, 2009; King, Davis, and Mintchik, 2012).

Information asymmetries between users of audited financial statements and management of the entity urge the SEC and PCAOB to protect the interests of financial statement users. Therefore, increased transparency and public disclosure regarding auditor independence is specifically addressed by the SEC and PCAOB. The increased accountability and public scrutiny associated with such disclosure can deter independence impairments by encouraging company management, audit committees, and auditors to more carefully evaluate the threats and safeguards surrounding auditor independence (SEC 2001; Church et al., 2018).

\subsection{Development of Hypotheses}

\subsubsection{Perceptions of Auditor Independence}

Given the apparent link between auditor independence, objectivity and financial reporting reliability, several studies about auditor independence have been conducted (Dopuch, King, and Schwartz, 2003; Martinov, 2005; Mednick, 1997; Orren, 1997; Pany and Reckers, 1988; Salehi, 2009; Sweeney, 1995), but like most topics in accounting research, the findings are mixed. However, since auditor independence in fact is unobservable, users' judgments about independence are based on perceptions.

AS 3101.09.g requires auditors to explicitly state that they are independent and have complied with appropriate independence regulations of the PCAOB and SEC (PCAOB 2017). There is a perception that independent auditors enhance the reliability of financial statements because they are able to exercise professional skepticism. With the explicit clarification, auditors are perceived to be more likely to prevent or detect, and appropriately, correct material misstatements or omissions either due to fraud or error, and to ensure that financial statements comply with generally accepted accounting principles. Users equate independence with objectivity. As a result, the PCAOB perceives that it will be helpful for auditors to explicitly reassure investors and other users of financial statements that they are independent of the companies they audit, that they understand their obligations to be independent. Given users' 
perception that independent auditors are gatekeepers of the public securities market, and are prone to issue reliable opinion, we propose and test the following hypothesis:

H1: An explicit clarification of auditor independence in the auditor's report will positively enhance equity analysts' perceptions of auditor independence.

\subsubsection{Perception of Financial Reporting Reliability}

Prior research has shown that an audit report adds credibility to a company's financial statements and facilitates stakeholders' decisions (Coram, Mock, Turner, and Gray, 2011; Doty, 2011). Since the enactment of the Sarbanes-Oxley Act (SOX) in 2002, regulators have advocated strengthening auditor independence as the ultimate solution to accounting scandals (AICPA, 2017; SEC, 2003; PCAOB, 2003). Posner (1974) posits that regulation is appropriate when there is a risk of market failure or a need to protect the public interest. Regulators seek to reduce information asymmetry by insisting on more disclosures to the financial reporting process.

According to a 2008 U.S Government Accountability Office report, users of financial statements expect auditors to bring integrity, independence, objectivity, and professional competence to the financial reporting process and prevent the issuance of misleading financial statements (Doty, 2011). Investors and other financial statement users staunchly believe that auditors have unique and relevant insight based on their audit (PCAOB, 2013). Proponents for the expanded auditor report claim that the inclusion of auditor independence statement will enhance users' confidence in financial reporting because users will be reassured that auditors are fully aware of their obligations to be independent. Therefore, based on the alleged link between auditor independence and financial reporting reliability, and the fact that the source of the assurance of independence is auditors themselves (credible third parties) we test the following hypothesis:

\section{H2: An explicit clarification of auditor independence in the auditor's report will positively enhance equity analysts' perceptions of financial reporting reliability.}

2.3.3 Importance of Explicit Clarification of Auditor Independence on Stock Recommendations

The objective of financial reporting is to provide users with reliable financial information to make investment and lending decisions (FASB, 2010). A perception that the auditor's work is more objective and independent inspires greater confidence in the auditor's opinion, thereby increasing the reliability of financial reports. The apparent positive association between auditor independence (stated explicitly in the auditor's report by auditors themselves) and financial reporting reliability would play a significant role in users' decision-making. We test this link with the following hypothesis:

\section{H3: An explicit clarification of auditor independence in the auditor's report will positively impact equity analysts' stock recommendations.}

\section{Methodology}

\subsection{Survey Instrument}

We administer a survey (see appendix A) via Qualtrics to evaluate equity analysts' perceptions of auditor independence and their investment judgments. Our survey instrument is created based on the practical literature of the PCAOB Rulemaking Docket Matter No. 034 on The Auditor's Report on an Audit of Financial Statements When the Auditor Expresses an Unqualified Opinion (PCAOB 2017). We also refer to the prior academic literature (Asare and Wright, 2012).

All 123 participants are asked to respond to a total of eleven questions to measure equity analysts' perceptions of the effects of an explicit clarification of auditor independence in the audited financial reports as proposed by the PCAOB (PCAOB 2013; 2017). The questionnaire consists of two parts. The first part includes eleven questions on explicit clarification of auditor independence as they relate to all three dependent variables, namely (1) four questions on perceptions of auditor independence, (2) four questions on perceptions of financial reporting reliability, and (3) three questions on likelihood of making stock recommendations. The second part contains nine questions related to respondents' demographic information, knowledge of internal control and auditor report, and use of financial statements.

A five-point scale, with $1=$ Strongly Disagree, $2=$ Disagree, $3=$ Neutral, $4=$ Agree, $5=$ Strongly Agree, is used. The purpose of the survey is to test the three hypotheses that we propose in the previous section. We received IRB approval from the respective institutions in order to administer the questionnaire via Qualtrics. 


\subsection{Participants}

We administer a nationwide survey via Qualtrics using equity analysts as respondents. Equity analysts are sophisticated professional investors because they are among investor groups who routinely analyze financial data and have inherent interests in the reliability of such data.

Participant demographics include gender, work experience, use of auditor reports, understanding of the auditor's opinion, understanding of internal control report, frequency of using financial statements, title of current position, highest education level attained, and professional certifications reports.

\subsection{Statistical Approach}

We employ descriptive statistics to describe the frequency distributions of responses about equity analysts' perceptions of auditor independence, perceptions of financial reporting reliability, and likelihood of making stock recommendations when the audit report explicitly clarifies auditors' independence. In addition, we also use one-sample t-test to determine whether the overall mean is significantly different from 3 (the middle point on the 5-point Likert scale). We also run Wilcoxon Signed Rank Test, one of the most commonly used nonparametric alternatives to the one-sample t-test.

The results of the Descriptive Statistics in terms of mean, median, frequencies, $\mathrm{p}$-value for one-sample t-test and p-value for Wilcoxon Signed Rank Test (WSRT) are tabulated to show responses of participants on the above mentioned three subcategories of the questionnaire.

\section{Survey Results}

\subsection{Participants' Descriptive Characteristics}

The sample consists of 123 responses from equity analysts recruited via Qualtrics. The demographic information in Table 1 indicates that participants are experienced and well qualified analysts (whose major job function is to analyze financial reports for investment purposes). According to Table 1,69\% of the respondents are male; $88 \%$ of the participants have over five years' experience as equity analysts. Also, $80 \%$ of the respondents use internal control reports on average or frequent basis, $92 \%$ of the respondents have average or full knowledge of the auditor's opinion, $88 \%$ of the participants have average or full understanding of internal control audit report, $91 \%$ of the respondents use financial reports on average or frequent basis. Seventy-four percent of the participants have a professional designation as Equity Analyst or Fund Manager. Ten of the 32 'other' respondents (about $9 \%$ ) are financial analysts, and the remaining 22 participants have various titles such as Accounting Analysts, Equity Derivatives V.P., Risk Analysts. Lastly, $94 \%$ of the respondents have either a bachelor's or master's degree.

The results of the survey are presented in terms of the following dimensions: perceptions of auditor independence; perceptions of financial reporting reliability; and likelihood of making stock recommendations. 
Table 1. Descriptive Statistics of the Respondents

\begin{tabular}{|c|c|c|}
\hline & Number of Respondents & Percentage \\
\hline \multicolumn{3}{|l|}{ Gender } \\
\hline Male & 85 & $69 \%$ \\
\hline Female & 38 & $31 \%$ \\
\hline \multicolumn{3}{|l|}{ Work Experience } \\
\hline $\begin{array}{l}\text { Greater than } 1 \text { year ar } \\
\text { less than } 5 \text { years }\end{array}$ & 15 & $12 \%$ \\
\hline \multicolumn{3}{|l|}{ Between 5 years and 10} \\
\hline More than 10 years & 64 & $52 \%$ \\
\hline \multicolumn{3}{|c|}{$\begin{array}{l}\text { Use of Internal Control } \\
\text { Audit Reports }\end{array}$} \\
\hline Rarely Use & 25 & $20 \%$ \\
\hline Average Use & 58 & $47 \%$ \\
\hline Frequently Use & 40 & $33 \%$ \\
\hline \multicolumn{3}{|c|}{$\begin{array}{l}\text { Your Understanding of } \\
\text { the Auditor's Opinion }\end{array}$} \\
\hline Limited & 10 & $8 \%$ \\
\hline Average & 51 & $42 \%$ \\
\hline Full & $\underline{62}$ & $50 \%$ \\
\hline \multicolumn{3}{|c|}{$\begin{array}{l}\text { Your Understanding of } \\
\text { Internal Control Report }\end{array}$} \\
\hline Limited & 14 & $11 \%$ \\
\hline Average & 51 & $42 \%$ \\
\hline Full & $\underline{58}$ & $47 \%$ \\
\hline \multicolumn{3}{|l|}{$\begin{array}{l}\text { How Often You Use } \\
\text { Financial Reports }\end{array}$} \\
\hline Rarely Use & 11 & $9 \%$ \\
\hline Average Use & 43 & $35 \%$ \\
\hline Frequently Use & $\underline{69}$ & $56 \%$ \\
\hline \multicolumn{3}{|l|}{ Your Job Title } \\
\hline Equity Analyst & 69 & $56 \%$ \\
\hline Fund Manager & 22 & $18 \%$ \\
\hline Other (Specify) & $\underline{32}$ & $26 \%$ \\
\hline \multicolumn{3}{|l|}{$\begin{array}{l}\text { Highest Educational } \\
\text { Level }\end{array}$} \\
\hline High School Diploma & 1 & $1 \%$ \\
\hline Bachelor's Degree & 59 & $48 \%$ \\
\hline Master's Degree & 57 & $46 \%$ \\
\hline Other (Specify) & $\underline{6}$ & $5 \%$ \\
\hline
\end{tabular}




\subsection{H1: Perceptions of Auditor Independence}

In the questionnaire, we utilize four general statements to assess users' perceptions of explicit clarification of auditor independence in the auditor's report, which is presented in Table 2. The Public Company Accounting Oversight Board (PCAOB) posits that if auditors explicitly clarify that they are independent of the company, it will enhance financial report users' understanding about the auditor's obligations related to independence and the statement will serve as a constant reminder.

Statement 1 states that: "Auditors should include an explicit clarification of auditor independence paragraph in the audit report to show they understand their obligations to be independent. A majority of respondents (77\%) either agree or strongly agree, $11 \%$ are neutral, while $12 \%$ either disagree or strongly disagree.

Table 2. General Statements on the PCAOB'S Clarification of Auditor Independence Requirement $(n=123)$

\begin{tabular}{|c|c|c|c|c|c|c|c|c|}
\hline & & & & rceptions & f Auditor & depender & & \\
\hline & & & Mean & SD & $\mathrm{D}$ & $\mathrm{N}$ & A & SA \\
\hline & & t-test ${ }^{2}$ & $(\mathrm{SD})$ & (1) & (2) & (3) & (4) & (5) \\
\hline \# & Statement $^{1}$ & (WSRT) & Count & Count & Count & Count & Count & Count \\
\hline & & & Percent & Percent & Percent & Percent & Percent & Percent \\
\hline 1 & Auditors should include an & & & & & & & \\
\hline & explicit clarification of & 0.000 & 3.96 & & & & & \\
\hline & paragraph in the audit report & $(0.000)$ & $(1.13)$ & 7 & 8 & 14 & 48 & 46 \\
\hline & to show they understand their & & 123 & $5.7 \%$ & $6.5 \%$ & $11.4 \%$ & $39.0 \%$ & $37.4 \%$ \\
\hline & $\begin{array}{l}\text { obligations to be } \\
\text { independent*. }\end{array}$ & & $100 \%$ & & & & & \\
\hline 2 & $\begin{array}{l}\text { An explicit clarification of } \\
\text { auditor independence stating }\end{array}$ & & 3.73 & & & & & \\
\hline & $\begin{array}{l}\text { that Auditors have followed } \\
\text { Securities and Exchange }\end{array}$ & 0.000 & $(1.02)$ & 4 & 12 & 24 & 56 & 27 \\
\hline & Commission rules will & $(0.000)$ & 123 & $3.3 \%$ & $9.8 \%$ & $19.5 \%$ & $45.5 \%$ & $22.0 \%$ \\
\hline & $\begin{array}{l}\text { enhance perceptions of } \\
\text { auditor independence*. }\end{array}$ & & $100 \%$ & & & & & \\
\hline 3 & An explicit clarification of & & 3.55 & & & & & \\
\hline & auditor independence in the & 0.000 & $(1.00)$ & 5 & 11 & 38 & 49 & 20 \\
\hline & perceptions of auditor & $(0.000)$ & 123 & $4.1 \%$ & $8.9 \%$ & $30.9 \%$ & $39.8 \%$ & $16.3 \%$ \\
\hline & independence*. & & $100 \%$ & & & & & \\
\hline 4 & An explicit clarification of & & & & & & & \\
\hline & $\begin{array}{l}\text { auditor independence } \\
\text { statement in the audit report }\end{array}$ & & 3.41 & & & & & \\
\hline & will remove all doubts about & 0.000 & $(1.10)$ & 6 & 21 & 33 & 43 & 20 \\
\hline & the auditor's independence*. & $(0.000)$ & 123 & $4.9 \%$ & $17.1 \%$ & $28.8 \%$ & $35.0 \%$ & $16.3 \%$ \\
\hline & & & $100 \%$ & & & & & \\
\hline
\end{tabular}

\footnotetext{
${ }^{1}$ Responses to General Statements are measured on a 1-5 scale, where 1=Strongly Disagree (SD), 2=Disagree (D), $3=$ Neutral (N), 4=Agree (A), and 5=Strongly Agree (SA);

${ }^{2}$ To determine how the mean scores of participants differ from the Median score of 3 (Neutral), a One-Sample Wilcoxon Signed Ranked Test and one-sample t-test are conducted; The results of Wilcoxon Signed Ranked Test on the above four statements are significant with p-values at 0.05 level or less (one-tailed). One-sample t-test has significant p-values at 0.05 level or less (two-tailed).
} 
Sixty-eight percent of the respondents either agree or strongly agree with Statement 2, "An explicit clarification of auditor independence stating that Auditors have followed Securities and Exchange Commission rules will enhance perceptions of auditor independence," while about $20 \%$ are neutral, and $12 \%$ either disagree or strongly disagree. For Statement 3, "An explicit clarification of auditor independence in the audit report will change perceptions of auditor independence," over 56\% either agree or strongly agree, while $13 \%$ either disagree or strongly disagree, and $31 \%$ are neutral. Finally, for Statement 4 "An explicit clarification of auditor independence statement in the audit report will remove all doubts about the auditor's independence," over 51\% of the respondents either agree or strongly agree, $22 \%$ either disagree or strongly disagree, while 27\% are neutral. The results of the Wilcoxon Signed Rank Test and t-test indicate that all four statements have p-values that are significant. The significant p-values indicate that participants are convinced that explicitly clarifying the independence of the auditor in the auditor's report as adopted in PCAOB (2017) would enhance users' understanding of the auditor's existing obligations to be independent, and also serve as a reminder to auditors of these obligations.

The results for Statements 1 to 4 suggest that, overall, equity analysts are in favor of adding explicit clarification of auditor independence statement to the auditor's report. Therefore, H1 is supported. This bolsters the argument that independence ultimately depends on perceptions rather than on facts. Explicit clarification of independence by auditors themselves will remove all skepticism about the auditor's independence and add credibility to the financial reporting process.

\subsection{H2: Perceptions of Financial Reporting Reliability}

This subsection of the survey contains four general statements that deal with analysts' perceptions of financial reporting reliability. For Statement 5, "An explicit clarification of auditor independence paragraph in the audit report will enhance financial reporting reliability," nearly $64 \%$ of participants either agree or strongly agree, $20 \%$ are neutral, and $16 \%$ either disagree or strongly disagree. Statement 6 states that "An explicit clarification of auditor independence will enhance the credibility of financial statements," approximately $63 \%$ either agree or strongly agree, $22 \%$ are neutral, and nearly $15 \%$ either disagree or strongly disagree. For Statement 7 "Auditors will be more likely to provide objective opinions on financial statements if the report contains explicit clarification of auditor independence statement," about half of the respondents either agree or strongly agree, $30 \%$ are neutral, while about $20 \%$ either disagree or strongly disagree. Statement 8 states that "Auditors will more likely seek appropriate corroborating evidence before accepting management's estimates and explanations if the report includes an explicit clarification of auditor independence statement," nearly $57 \%$ of respondents either agree or strongly agree, $26 \%$ are neutral, and about $27 \%$ either disagree or strongly disagree. 
Table 3. General Statements on the PCAOB'S Clarification of Auditor Independence Requirement $(n=123)$

\begin{tabular}{|c|c|c|c|c|c|c|c|c|}
\hline & & \multicolumn{7}{|c|}{ (Perceptions of Financial Reporting Reliability) } \\
\hline \multirow{4}{*}{ \# } & & & Mean & SD & $\mathrm{D}$ & $\mathrm{N}$ & $\mathrm{A}$ & SA \\
\hline & & t-test & (SD) & (1) & $(2)$ & (3) & (4) & $(5)$ \\
\hline & \multirow[t]{2}{*}{ Statement $^{1}$} & (WSRT) & Count & Count & Count & Count & Count & Count \\
\hline & & & Percent & Percent & Percent & Percent & Percent & Percent \\
\hline \multirow[t]{4}{*}{5} & $\begin{array}{l}\text { An explicit clarification of } \\
\text { auditor independence }\end{array}$ & 0.000 & 3.67 & & & & & \\
\hline & report will enhance & $(0.000)$ & $(1.05)$ & 3 & 17 & 25 & 50 & 28 \\
\hline & financial reporting & & 123 & $2.4 \%$ & $13.8 \%$ & $20.3 \%$ & $40.7 \%$ & $22.8 \%$ \\
\hline & reliability*. & & $100 \%$ & & & & & \\
\hline \multirow[t]{4}{*}{6} & $\begin{array}{l}\text { An explicit clarification of } \\
\text { auditor independence will }\end{array}$ & & 3.65 & & & & & \\
\hline & financial statements*. & 0.000 & $(.975)$ & 2 & 16 & 27 & 56 & 22 \\
\hline & & $(0.000)$ & 123 & $1.6 \%$ & $13.0 \%$ & $22.0 \%$ & $45.5 \%$ & $17.9 \%$ \\
\hline & & & $100 \%$ & & & & & \\
\hline \multirow[t]{5}{*}{7} & Auditors will be more & & & & & & & \\
\hline & $\begin{array}{l}\text { likely to provide objective } \\
\text { opinions on financial }\end{array}$ & & 3.41 & & & & & \\
\hline & statements if the report & 0.000 & $(1.06)$ & 6 & 18 & 37 & 44 & 18 \\
\hline & contains explicit & $(0.000)$ & 123 & $4.9 \%$ & $14.6 \%$ & $30.1 \%$ & $35.8 \%$ & $14.6 \%$ \\
\hline & $\begin{array}{l}\text { clarification of auditor } \\
\text { independence statement*. }\end{array}$ & & $100 \%$ & & & & & \\
\hline \multirow[t]{5}{*}{8} & Auditors will be more & & & & & & & \\
\hline & $\begin{array}{l}\text { likely to seek appropriate } \\
\text { corroborating evidence }\end{array}$ & & 3.53 & & & & & \\
\hline & before accepting & 0.000 & $(1.05)$ & 5 & 16 & 32 & 49 & 21 \\
\hline & management's estimates & $(0.000)$ & 123 & $4.1 \%$ & $13.0 \%$ & $26.0 \%$ & $39.8 \%$ & $17.1 \%$ \\
\hline & $\begin{array}{l}\text { and explanations if the } \\
\text { report includes an explicit } \\
\text { clarification of auditor } \\
\text { independence statement*. }\end{array}$ & & $100 \%$ & & & & & \\
\hline
\end{tabular}

\footnotetext{
${ }^{1}$ Responses to General Statements are measured on a 1-5 scale, where 1=Strongly Disagree (SD), 2=Disagree (D), 3=Neutral (N), 4=Agree (A), and 5=Strongly Agree (SA);

2 To determine how the mean scores of participants differ from the Median score of 3 (Neutral), a One-Sample Wilcoxon Signed Ranked Test and one-sample t-test are conducted; The results of Wilcoxon Signed Ranked Test on the above four statements are significant with p-values at 0.05 level or less (one-tailed). One-sample t-test has significant p-values at 0.05 level or less (two-tailed).
}

The results of the Wilcoxon Signed Rank Test and one-sample t-test indicate that all four statements have p-values that are significant. This implies that most of the participants concur with the PCAOB's assertion that an explicit statement in the auditor's report clarifying the auditor's independence will enhance financial report users' confidence. The above results for Statements 5, 6, 7, and 8 suggest that an explicit statement clarifying the auditor's independence will enhance equity analysts' confidence in financial statements and boost financial reporting reliability. The results support the new standard, AS 3101 .09.g. Hence, H2 is supported. 


\subsection{H3: Likelihood of Making Stock Recommendations}

This subsection discusses the results of participants' responses to three general statements on the likelihood of relying on audited financial reports when making stock recommendation on a daily basis (buy, hold, or sell). Table 4 summarizes participants' mean response scores, standard deviation (SD), response count and related percentages, and p-values on the Wilcoxon Signed Rank Test and one-sample t-test.

Statement 9 states that an explicit clarification of auditor independence in the audit report will be more helpful to analysts when making investment recommendations. More than half of participants (54\%) either agree or strongly agree, $27 \%$ are neutral, while $19 \%$ either disagree or strongly disagree. Statement 10 states that an explicit clarification of auditor independence in the audit report will greatly enhance the likelihood of analysts relying on financial reports to make investing recommendations to their clients. Approximately, half of the respondents (50\%) either agree or strongly agree, $19 \%$ either disagree or strongly disagree, and $31 \%$ are neutral.

Statement 11 states that an explicit clarification of auditor independence in the audit report will boost the confidence of analysts when making investing recommendations to clients. While $27 \%$ of participants are neutral on this, 59\% either agree or strongly agree, and $13.9 \%$ either disagree or strongly disagree.

The results of the Wilcoxon Signed Rank Test and one-sample t-test on Table 4 show significant p-values for all three statements. The test indicates significant scores relative to the 3-point neutral position for each of the statements.

Table 4. General Statements on the PCAOB'S Clarification of Auditor Independence Requirement $(n=123)$

\begin{tabular}{|c|c|c|c|c|c|c|c|c|}
\hline & & \multicolumn{7}{|c|}{ (Likelihood of Making Stock Recommendations) } \\
\hline \multirow{4}{*}{ \# } & \multirow{4}{*}{ Statement $^{1}$} & & Mean & SD & $\mathrm{D}$ & $\mathrm{N}$ & $\mathrm{A}$ & SA \\
\hline & & t-test & $(\mathrm{SD})$ & (1) & $(2)$ & (3) & (4) & $(5)$ \\
\hline & & (WSRT) & Count & Count & Count & Count & Count & Count \\
\hline & & & Percent & Percent & Percent & Percent & Percent & Percent \\
\hline \multirow[t]{5}{*}{9} & \multirow{5}{*}{$\begin{array}{l}\text { An explicit clarification } \\
\text { of auditor independence } \\
\text { statement in the audit } \\
\text { report will be helpful to } \\
\text { analysts when making } \\
\text { investing } \\
\text { recommendations*. }\end{array}$} & & & & & & & \\
\hline & & & 3.46 & & & & & \\
\hline & & 0.000 & $(1.02)$ & & & & & \\
\hline & & $(0.000)$ & 123 & 4 & 19 & 33 & 50 & 17 \\
\hline & & & $100 \%$ & $3.3 \%$ & $15.4 \%$ & $26.8 \%$ & $40.7 \%$ & $13.8 \%$ \\
\hline \multirow[t]{3}{*}{10} & \multirow{3}{*}{$\begin{array}{l}\text { An explicit clarification } \\
\text { of auditor independence } \\
\text { statement in the audit } \\
\text { report will enhance the } \\
\text { likelihood of } \\
\text { recommending investing } \\
\text { in the stock of a } \\
\text { company*. }\end{array}$} & & $\begin{array}{l}3.38 \\
(1.05)\end{array}$ & & & & & \\
\hline & & 0.000 & 123 & 7 & 16 & 39 & 45 & 16 \\
\hline & & $(0.000)$ & $100 \%$ & $5.7 \%$ & $13.0 \%$ & $31.7 \%$ & $36.6 \%$ & $13.0 \%$ \\
\hline \multirow[t]{3}{*}{11} & \multirow{3}{*}{$\begin{array}{l}\text { An explicit clarification } \\
\text { of auditor independence } \\
\text { statement in the audit } \\
\text { report will boost the } \\
\text { confidence of analysts } \\
\text { when making investment } \\
\text { recommendations*. }\end{array}$} & & $\begin{array}{l}3.59 \\
(.999)\end{array}$ & & & & & \\
\hline & & 0.000 & 123 & 4 & 13 & 33 & 52 & 21 \\
\hline & & $(0.000)$ & $100 \%$ & $3.3 \%$ & $10.6 \%$ & $26.8 \%$ & $42.3 \%$ & $17.1 \%$ \\
\hline \multicolumn{9}{|c|}{$\begin{array}{l}{ }^{1} \text { Responses to General Statements are measured on a 1-5 scale, where 1=Strongly Disagree (SD), 2=Disagree (D), } \\
3=\text { Neutral }(\mathrm{N}), 4=\text { Agree (A), and 5=Strongly Agree (SA); }\end{array}$} \\
\hline \multicolumn{9}{|c|}{$\begin{array}{l}2 \text { To determine how the mean scores of participants differ from the Median score of } 3 \text { (Neutral), a One-Sample } \\
\text { Wilcoxon Signed Ranked Test and one-sample t-test are conducted; The results of Wilcoxon Signed Ranked Test } \\
\text { on the above four statements are significant with p-values at } 0.05 \text { level or less (one-tailed). One-sample t-test has } \\
\text { significant p-values at } 0.05 \text { level or less (two-tailed). }\end{array}$} \\
\hline
\end{tabular}


Statements 9 to 11 evaluate the likelihood that equity analysts would rely on an expanded audited financial report that includes clarification of auditor independence when making stock recommendations. The results indicate that an explicit clarification of auditor independence statement in the auditor's report will be helpful to analysts when making investment-related decisions. Therefore, H3 is supported.

\section{Discussion}

\subsection{Conclusions and Implications}

In summary, the additional disclosure of auditor independence will make the report more informative and provide the needed assurance that the auditor is independent in fact and in appearance. Specifically, an explicit clarification of auditor independence statement will enhance users' understanding of the auditor's existing obligations to be independent and serve as a constant reminder to auditors of these obligations. The wider implication of the above finding is that an expanded auditor's report would change negative perceptions about auditor independence and encourage reliance on the auditor's report to make important stock recommendations. The addition of explicit clarification of auditor independence statement will make the report conform to IAASB's similar standard, Forming an Opinion and Reporting on Financial Statements (IAASB 2015).

The results of the survey suggest that equity analysts support the inclusion of explicit clarification of auditor independence in the auditor's report. Most of the respondents believe that the inclusion of auditor independence statement in the report would remove any lingering doubts about the auditor's independence, enhance their perceptions of financial reporting reliability, and inform their judgments. Moreover, the clarification statement will make the financial reports a valuable source of financial information for investing decisions. The favorable response means that the intended objective of making the audit report more informative and relevant to users as envisaged by the new standard (PCAOB, 2017) will be achieved with the addition of auditor independence statement. Thus, our finding supports the PCAOB's contention that a clarification statement will constantly remind auditors of their obligation to be independent of their clients.

\subsection{Contributions}

This study contributes to research, practice, and policy. Firstly, the study finds that the addition of explicit clarification of auditor independence statement to the auditor's report enhances the informative value of the report. This echoes the finding of other previous studies that concluded that additional information disclosures are helpful to analysts because such disclosures add some degree of credibility and transparency to the audit process (Manson and Zaman, 2001; Davis, 2007). The study lends credence to Manson and Zaman's (2003) contention that any additional relevant financial disclosures are beneficial in improving users' judgments and market outcomes. Secondly, explicitly clarifying the auditor's obligations to be independent reminds auditors of their obligations, which in turn mitigates the misperceptions some users of financial reports have about auditor independence. Finally, the finding that a clarified audit report will enhance financial reporting strengthens the stance of the PCAOB because it provides first-hand information provided by experts who use financial information on a daily basis. The concept of clarification of auditor independence in the auditor's report supports the view that any empirical evidence is a source of immense help to regulators, researchers and practitioners of accounting as a whole, and auditors in particular.

\subsection{Limitations}

In spite of the contributions described above, our study has some limitations. While equity analysts are important stakeholders whose understanding and use of financial reports deserve study, other stakeholders especially attorneys and non-professional investors may have motives that predispose them to interpret the data provided in the survey in a different way. Future research may investigate how a statement that explicitly clarifies the auditor's independence impacts other users' confidence in financial reporting and investing judgments. Also, all surveys involve presenting respondents with a series of questions for them to answer, so the data is basically what respondents say to the questions. Thus, replicating the study using other stakeholders, a different questionnaire and a different method of data analysis will be worthwhile.

\section{References}

American Institute of Certified Public Accountants (AICPA). (2010). Auditing Standards Board (ASB) meeting, June 21-24, $2010 . \quad$ Available at http://www.aicpa.org/Research/Standards/AuditAttest/ASB/Documents/Mtg/1006/2010_06_ASB_Highlights.p df. 
American Institute of Certified Public Accountants (AICPA). (2017). AICPA Plain English Guide to Independence. Available https://www.aicpa.org/interestareas/professionalethics/resources/tools/downloadabledocuments/plain\%20englis h\%20guide.pdf.

Asare, S.K., \& Wright, A.M. (2012). Investors', Auditors', and Lenders' understanding of the message conveyed by the standard audit report on the financial statements. Accounting Horizons, 26(2), 193-217. https://doi.org/10.2308/acch-50138

Barlev, B., Citron, D. B., \& Haddad, J. R. (2017). Who Is Afraid of Transparency? Accounting \& the Public Interest, 17(1), 60-83. https://doi.org/10.2308/apin-51758

Brinol, P., \& Petty, R. E. (2009). Source factors in persuasion: A self-validation approach. European Review of Social Psychology, 20(1), 49-96. https://doi.org/10.1080/10463280802643640

Carey, J. L. (1946). Professional ethics of public accounting. American Institute of Accountants.

Christensen, B. E., Glover, S. M., Omer, T. C. \& Shelley, M. K. (2016). Understanding audit quality: Insights from audit professionals and investors. Contemporary Accounting Research, 33(4), 1648-1684. https://doi.org/10.1111/1911-3846.12212

Church, B. K., Jenkins, G., \& Stanley, J.D. (2018). Auditor Independence in the United States: Cornerstone of the Profession or Thorn in Our Side? Accounting Horizons, 32(3), 145-168. https://doi.org/10.2308/acch-52122

Church, B.K., \& Zhang, P. (2002). Independence in Appearance: Non-auditing Services and Auditor Fee Disclosures, Working Paper, Toronto University.

Coram, P., Mock, T., Turner, J. \& Gray, G. (2011). The communicative value of the auditor's report. Australian Accounting Review, 21(3), 235-252. https://doi.org/10.1111/j.1835-2561.2011.00140.x

Davis, J. S. (2011). Insights from assurance analogs. Accounting, Organizations and Society, 36(4), $313-317$. https://doi.org/10.1016/j.aos.2011.07.001

Dopuch, N., King, R., \& Schwartz, R. (2003). Independence in appearance and in fact: An experimental investigation. Contemporary Accounting Research, $20(1), \quad 279-314$. https://doi.org/10.1506/9B5D-HLLP-BBQE-8N3F

Doty, J. R. (2011). The relevance, role, and reliability of audits in the global economy. Texas Law Review, 90, 1892-1911.

Doty, J. R. (2015). Protecting the Investing Public's Interest in Informative, Accurate, and Independent Audit Reports. AICPA Conference on Current SEC and PCAOB Developments, Keynote Address, Washington, DC, December 9. Available at: https://pcaobus.org/News/Speech/Pages/Doty-AICPCA-2015-keynote.aspx

Easley, D., \& O'Hara, M. (2004). Information and the cost of capital. The Journal of Finance, 59, $1553-1583$. https://doi.org/10.1111/j.1540-6261.2004.00672.x

Elliot, R. K., \& Jacobson, P. D. (1998). Audit independence concepts, The CPA Journal, December.

Financial Accounting Standards Board (FASB). (1978). Statement of Financial Accounting Concepts: No. 1 Objectives of Financial Reporting by Business Enterprises. Available at: https://www.fasb.org/resources/ccurl/816/894/aop_CON1.pdf.

Financial Accounting Standards Board (FASB). (2010). Chapter 1, The Objective of General Purpose Financial Reporting and Chapter 3, Qualitative Characteristics of Useful Financial Information. Statement of Financial Accounting Concepts No. 8. Stamford, CT:FASB.

Holt T. P. \& DeZoort,T. (2009). The effects of internal Audit report disclosure on investor confidence and investment decisions. International Journal of Auditing, 13(1), 61-77. https://doi.org/10.1111/j.1099-1123.2008.00391.x

The International Auditing and Assurance Standards Board (IAASB). (2011). International Standard on Auditing (ISA) (IAASB). Enhancing the Value of Auditor Reporting: Exploring Options for Change. New York, NY: International Federation of Accountants, 35.

The International Auditing and Assurance Standards Board (IAASB). (2015). International Standard on Auditing (ISA) 700 (Revised), Forming an Opinion and Reporting on Financial Statements. Available at 
https://www.ifac.org/publications-resources/international-standard-auditing-isa-700-revised-forming-opinion-an d-reporting.

King, R. R., Davis, S. M., \& Mintchik, N. (2012). Mandatory disclosure of the engagement partner's identity: Potential benefits and unintended consequences. Accounting Horizons, 26(3), 533-561. https://doi.org/10.2308/acch-50201

Manson, S., \& Zamon, M. (2001). Auditor communication in an evolving environment: Going SAS 600 auditors' reports of financial statements. The British Accounting Review, 33(2), 113-136. https://doi.org/10.1006/bare.2001.0157

Martinov, N. (2005). An investigation of the Moral Intensity Construct on Auditors' Decision Making and Independence. University of New South Wales.

Mednick, R. (1997). Chair's Corner. The CPA Letter (June) 10.

Moore, D. A., Tetlock, P. E., \& Tanlu, L. (2006). Conflicts of interest and the case of auditor independence: Moral seduction and strategic issue cycling. Academy of Management Review, 31(1), 10-29. http://dx.doi.org/10.2307/20159182

Ofori-Mensah, K., Zhang, X., \& Booker, B. (2018). The effects of an explicit clarification of auditor independence on equity analysts' confidence in financial reporting and stock recommendations. Journal of Accounting \& Finance, 18(8), 101-118.

Orren, G. (1997). The appearance Standard on Audit Independence: What We Know and What We Should know? A Report Prepared on Behalf of the AICPA in Connection with the presentation to the Independence Standard Board.

Pany, K., \& Reckers, P. (1988). Auditor performance of MAS: A study of its effects on decisions and perceptions. Accounting Horizons, (June), 31-48.

Posner, R. (1974). Theories of economic regulation. The Bell Journal of Economics and Management Science, 5(2), 335-358.

Public Company Accounting Oversight Board (PCAOB). (2003). General Auditing Standards AS 1005: Independence. Available at https://pcaobus.org/Standards/Auditing/Pages/AS1005.aspx

Public Company Accounting Oversight Board (PCAOB). (2013). Proposed Auditing Standards on the Auditor's Report and the Auditor's Responsibilities Regarding Other Information and Related Amendments. August 13, 2013. Available at: http://pcaobus.org/Rules/Rulemaking/Docket034/Release_2013-005_ARM.pdf

Public Company Accounting Oversight Board (PCAOB). (2017). The auditor's report on an audit of financial statements when the auditor expresses and unqualified opinion and related amendments to PCAOB standards. PCAOB Release No. 2017-001 June 1, 2017. Available at https://pcaobus.org/Rulemaking/Docket034/Concept_Release.pdf

Ryan, S. G., R. H. Herz, T.E. Iannaconi, L. A. Maines, K. Palepu, C. M. Schrand, D. J. Skinner \& L. Vincent. (2001). Accounting Horizons, 15(4), 373-386.

Salehi, M. (2009). In the name of independence: with regard to practicing non-audit services by external auditors. International Business Research, 2(2), 137-147. https://doi.org/10.5539/ibr.v2n2p137

Securities and Exchange Commission (SEC). (2001). Commission Policy Statement on the Establishment and Improvement of Standards Related to Auditor Independence. Available at: https://www.sec.gov/rules/policy/33-7993.htm

Securities and Exchange Commission (SEC). (2003). Final Rule: Revision of the Commission's Auditor Independence Requirements. Washington, DC: SEC. Available at: https://www.sec.gov/rules/final/33-7919.htm.

Securities and Exchange Commission (SEC). (2017). Public Company Accounting Oversight Board; Order Granting Approval of Proposed Rules on the Auditor's Report on an Audit of Financial Statements When the Auditor Expresses an Unqualified Opinion, and Departures from Unqualified Opinions and Other Reporting Circumstances, and Related Amendments to Auditing Standards. Release No. 34-81916; File No. PCAOB-2017-01. Available at https://www.sec.gov/rules/pcaob/2017/34-81916.pdf 
Sweeney, J. T. (1995). The moral expertise of auditors: An exploratory analysis. Research on Accounting Ethics, (1), 213-234.

Tepalagul, N. \& L. Lin. (2015). Auditor Independence and Audit Quality: A Literature Review. Journal of Accounting, Auditing \& Finance, 30(1), 101-121. https://doi.org/10.1177/0148558X14544505

\section{Appendix: Questionnaire}

INSTRUCTIONS: The Questionnaire consists of general statements on the auditor' report regarding the addition of clarification of auditor independence statement in the auditor's report. The Public Company Accounting Oversight Board's proposed new reporting standards will require auditors to include the following clarifying language in the audit report:

"We are a public accounting firm registered with the Public Company Accounting Oversight Board ('PCAOB') of the United States, and are required to be independent with respect to the Company in accordance with the United States federal securities laws and the applicable rules and regulations of the Securities and Exchange Commission ('SEC') and the PCAOB."

Hereafter, we will refer to the proposed language above as "an Explicit Clarification of auditor Independence."

Please, respond to the statements below by indicating the extent of your agreement with each statement, using the following scale, and by circling the number that corresponds with your choice:

$$
\text { [1 = Strongly Disagree; } 2 \text { = Disagree; } 3 \text { = Neutral; } 4 \text { = Agree; } 5 \text { = Strongly Agree }] \text {. }
$$

\section{Perceptions of Auditor Independence}

1. Auditors should include an explicit clarification of auditor independence in the audit report to show they understand their obligations to be independent.

[1 = Strongly Disagree; 2 =Disagree; 3 = Neutral; 4 = Agree; 5 = Strongly Agree $]$.

2. An explicit clarification of auditor independence stating that auditors are required to be independent will enhance analysts' perception of auditor independence.

[1 = Strongly Disagree; 2 =Disagree; 3 = Neutral; 4 = Agree; 5 = Strongly Agree $]$.

3. An explicit clarification of auditor independence in the audit report will change perceptions of auditor independence.

[1 = Strongly Disagree; 2 =Disagree; 3 = Neutral; 4 = Agree; 5 = Strongly Agree $]$

4. An explicit clarification of auditor independence in the audit report will remove all doubts about the auditor's independence.

[1 = Strongly Disagree; 2 = Disagree; 3 = Neutral; 4 = Agree; $5=$ Strongly Agree $].$

\section{Perceptions of Financial Reporting Reliability}

5 An explicit clarification of auditor independence in the audit report will enhance perceptions of financial reporting reliability.

[1 = Strongly Disagree; 2 =Disagree; $3=$ Neutral $; 4=$ Agree; $5=$ Strongly Agree $]$.

6. An explicit clarification of auditor independence will enhance the credibility of audited financial statements.

[1 = Strongly Disagree; 2 =Disagree; 3 = Neutral; 4 = Agree; 5 = Strongly Agree $]$.

7. Auditors will be more likely to provide objective opinions on financial statements if the report includes an explicit clarification of auditor independence.

[1 = Strongly Disagree; 2 = Disagree; 3 = Neutral; 4 = Agree; $5=$ Strongly Agree $]$.

8. Auditors will be more likely to seek appropriate corroborating evidence before accepting management's estimates and explanations if the report includes an explicit clarification of auditor independence.

[ 1 = Strongly Disagree; 2 = Disagree; 3 = Neutral; 4 = Agree; $5=$ Strongly Agree . 


\section{Likelihood of Making Stock Recommendations}

9. An explicit clarification of auditor independence in the audit report will be helpful to analysts when making stock recommendations.

[ 1 = Strongly Disagree; 2 = Disagree; 3 = Neutral; 4 = Agree; 5 = Strongly Agree .

10. An explicit clarification of auditor independence in the audit report will enhance the likelihood of making stock recommendations.

[1 = Strongly Disagree; 2 = Disagree; 3 = Neutral; 4 = Agree; 5 = Strongly Agree .

11. An explicit clarification of auditor independence in the audit report will boost confidence of analysts when they make stock recommendations.

[1 = Strongly Disagree; 2 = Disagree; 3 = Neutral; 4 = Agree; 5 = Strongly Agree $].$

\section{Demographic Information}

Please provide the following information about yourself by placing a check-mark in the spaces provided.
(a). Gender:
Male........Female
(b). Work Experience: $>\mathbf{1 y r}$ but $<\mathbf{5}$ years 5-10 years More than 10 years......
(c). Your use of audit reports: Rarely Occasionally Frequently
(d). Your understanding of the auditor's opinion: Limited Average........Full
(e). Your understanding of internal control report:
Limited. Average.... Full......
(f). How often do you use financial statements: Rarely ... Occasionally ....Frequently ....
(g). Title of your current position:
1. Equity analyst.......
2. Fund manager
3. Other (Please specify).
(h). Highest Educational Level attained:
1. High School.
2. Bachelor's Degree.......
3. Master's Degree
4. Other (Please specify)
(i). Professional Certifications:
1. CPA.
2. CFP ..........
3. Other (please specify). 